\title{
ACADEMIC COUNSELLING IN ODL: Information System for Capacity Building of Academic Counselors' in IGNOU
}

\author{
Dr. S. KISHORE \\ Deputy Director, Indira Gandhi National Open University \\ Regional Centre, Sikkandar Chavadi, \\ Alanganallur Road, Madurai-625018. \\ Tamilnadu, INDIA
}

\section{ABSTRACT}

Indira Gandhi national Open University (IGNOU) is an apex body for open and distance learning (ODL) system in India. The university has nation-wide operation and pioneer in distance education. IGNOU has an hqrs, 67 Regional Centres and about 3400 Study Centres throughout India. The study centres are the academic contact point for distance learners and the university engages around 54,000 academic counsellors for giving learner support to the heterogeneous distance learners.

In IGNOU, the academic counsellors are mostly drawn from the formal higher educational system and the exposure towards ODL system therefore, is minimal. However, the academic counsellors are the pivotal link between the ODL institution and isolated distance learners in IGNOU. Their role in handling face-to-face academic counseling sessions at the study centre is very important. The academic counsellors in IGNOU are drawn from the conventional system of higher education. Though, periodical training is given to them by IGNOU, it is a difficult task to train such a massive number of counsellors across the country. In fact the role of an academic counsellor is multifarious and requires both tutoring and counseling. For maintaining quality in academic counseling, the accumulation of multi-dimensional skills, attributes and information is essential on the part of the cunsellor in ODL. Among these, possessing information at various levels about ODL system is an enabling factor to effectively support isolated distance learner.

Therefore, a comprehensive Information System is felt the need of the hour for the capacity building of the academic counsellors in supporting distance learners and for the quality assurance process. This work explores and builds a comprehensive information system for the academic counsellors in an ODL system, keeping IGNOU as the context.

Keywords: Open and distance learning; IGNOU; acdemic counseling; acdemic counsellor; Information system; Capacity building.

\section{INTRODUCTION}

Open and Distance Learning (ODL) institutions emerged in a developing country like India to promote higher education and play a vital role in accommodating the aspirants, especially adult learners in getting accommodated in the higher education sector. 
The Gross Enrolment Ratio (GER) in higher education in India is around $17 \%$ at present and this is well below the world average of $24 \%$.

It is opined that ODL system is the answer in the developing country like India to raise the GER in higher education and in this context ODL system gains much significance in the present scenario. Indira Gandhi National Open University (IGNOU), functioning at the national level for almost three decades, made considerable progress and gives equity and access to those who could not join the formal mode of higher education.

IGNOU is an apex institution for coordinating and maintaining standards of ODL in the country. At present, IGNOU is a system leader in India serving 3 million distance learners and enrolling 0.6 million learners every year. The learner support is managed by a network of 67 Regional Centres and around 3400 study centres all over the country with the support of 54,000 qualified academic counsellors drawn from conventional system of higher learning (IGNOU Profile, 2013). IGNOU has given importance to multimedia technologies like VCD, Gyan Vani radio broadcast, Gyan Darshan TV Channel, Teleconferencing and two-way video-conferencing facilities as supplement media besides the print material (self-learning material). However, the target learners of IGNOU are adult learners having different social, economic, educational backgrounds.

The marginalized sections of the society including those from rural and minority backgrounds are being served by IGNOU.

Therefore, it is not surprising that the heterogeneous distance learners of IGNOU prefer to attend the face-to-face academic counseling at the study centres and the academic counselors' at the study centres are considered as the link between IGNOU and the distance learners.

As a result it is not a far reaching idea to arrive at the fact that the academic counselors' at the study centres of IGNOU have a very important role in the management of academic counseling sessions as well as in maintaining the quality of ODL. On other hand, the learners of IGNOU also see a human face at the study centre in the form of academic counselors'.

\section{ACADEMIC COUNSELLING IN IGNOU}

The levels of programmes offered at IGNOU are Certificate, Diploma, Bachelors and Masters Degree. The number of programmes offered at these levels is around 200 . The university decides the study hours or workload of learners' based upon the number of credits. For instance, a learner has to work for 16 credits (1credit $=\mathbf{3 0}$ study hours) for six months certificate programmes whereas the workload for study is 32 credits for programmes of one year duration. In case of programmes of more than one year duration, the study work load is in multiples of 32 credits (i.e., $3 \times 32=96$ for Bachelors' degree programme.)

In IGNOU, out of the total study hours in terms of credits to be completed, $10 \%$ of the studies hours are covered through the face-to face academic counselling at the study centres. The remaining $90 \%$ of the study hours is to be undertaken by learners through self-study with the help of Self-Learning Materials (SLM), writing assignments, getting multimedia support etc. 
Even though, the counseling sessions allotted are very minimal, only during the counseling sessions the learners come into direct contact with the academic counsellor and their peer groups. For any distance learner, the academic counseling sessions are very important. The sessions are meant for Informing, Advising and Counseling (Koul and Bhatt, 1989). As per Koul, 1989, informing is defined as giving relevant information about the institution and programme of study and it is largely independent of the learner.

Advising is considered as the extending response as per the requirements and needs of the individual learner and always is learner dependent. In case of counseling, it is defined as the help or the guidance given to the learner and it is again learner dependent and neither knowledge nor institution based.

The academic counseling can cover both academic and non-academic components from at the various stages like at pre-entry, during entry to the programme, during the course of study, at the time of examination and during post-study (Koul,1989).

An in-depth picture of academic counseling comprises of Tutoring and Counselling. In fact both the terms are interchangeable. Tutoring primarily deals with academic component in enabling learning whereas the term counselling deals with communication both at the academic as well as at non-academic levels and learner-centred. In academic counseling, the emphasis is to be given more to the non-academic communication and tutoring should be restricted to minimum possible level. The reason is that the SLM in IGNOU provides the entire content and course requirement in a structured and programmed format.

In a nutshell, academic counseling is to cover the following components:

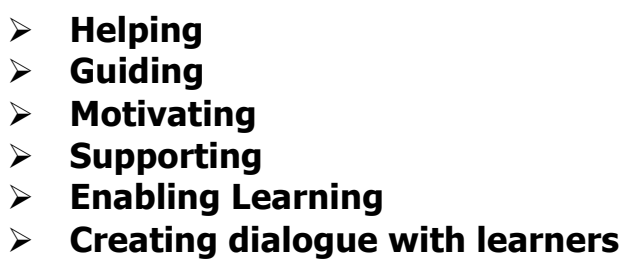

\section{EXPECTATIONS OF ACADEMIC COUNSELLORS IN IGNOU}

The academic counsellors are the vital link between the distance learners and the institution. They are only the human link during study period at the study centres and in spite of the fact that the academic counselling sessions are minimal in IGNOU, the sessions are expected to create vibrant interactivity for the learners with both the counsellors and peer groups. In IGNOU, the academic counsellors are the faculty members drawn from the conventional higher education system.

Consequently, the academic counsellors have the dual role to play in their twin job profiles. During the first five to six week days, they are classroom teachers and during week-ends, they have to play the role of academic counsellors in the ODL system. It is well known that the conventional system of higher education is teacher-oriented while the ODL system is learner-oriented. The classroom teaching strategies of formal system cannot be practiced or implemented in an ODL system. 
In such a situation, the counsellors drawn from formal system tend to have the mind set towards lecture-orientation rather than learner-orientation. This led to a situation where the academic counsellors of ODL system require continuous training and re-training in ODL system. The training needs of academic counsellors and notions of academic counseling were the focus of study as early as in 1996 (Murugan, 1996).

The core ODL Tutoring skills was also explained in detail (Tutoring in Open and Distance Learning: A Handbook for Tutors, COL, 2003) as follows:

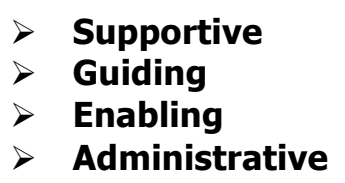

The ability of counsellors to deal with the complexities of academic counselling (counselling and tutoring) and provide distance teaching to learners was also formed part of a study (Srivastava and Reddy, 2002). In addition, an in-depth analysis was made (Mishra, 2005) to spell out the list of generic competencies required to perform as an academic counsellor in ODL.

Similarly, the key five attributes like inquiry, creativity, technological capabilities, entrepreneurial and moral leadership for enhancing the competencies of academic counsesllors are discussed in a recent study (Das and Ghosh, 2011).

From the above studies, it is pertinent that the much significance is attached to the aspects like skills, competencies and attributes to be a successful academic counsellor in an ODL system. It was way backing (Koul, 1989) in 1989, the author spells about the skills of the academic counsellors as follows:

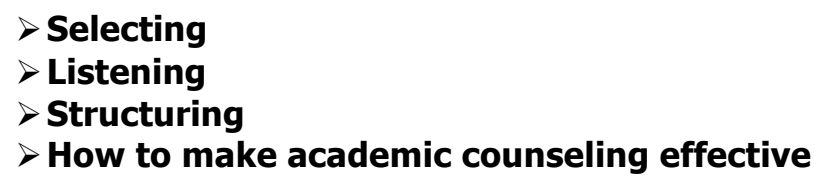

Following qualities are also required for an academic counsellor from the perspectives of academic counselling (Koul, 1989):

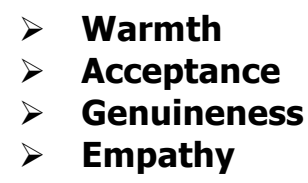

Having traced the studies made about the skills, attributes, attributes, competencies to be fulfilled by the academic counsellors in ODL system, the moot or very important question comes to the mind is-Is it possible to act as an effective academic counsellor with the training and competencies gained?. As far the experience goes in IGNOU, the academic counsellors are subject to regular orientation or training in the various aspects related to the academic counselling. However, still the academic counsellors engaged are not able to meet the complete expectations of ODL system, especially in IGNOU. 
The first reason is that there may be lack of application of skills gained in the training programmes at the time of the academic counselling sessions and there may be a lot of scope on the part of academic counsellors to improve the delivery of academic counseling sessions. Secondly, the academic counsellors feel that the sessions are meant to deal with the academic communication (tutoring) and in the process the significance of the term 'counselling' is to a greater extent got obliterated. Therefore, the expected role of an academic counselor is not fully reflected in the sessions. If so, the following questions emerge:

$>$ What is expected from an academic counsellor in ODL system

$>$ Is the academic counsellor able to think out-of-box and offer solutions to the distance learners

$>$ Is the learner satisfied with the academic counsellor during the sessions

$>$ Whether the academic counsellor is able to disseminate learner- linked information

$>$ Is the academic counsellor maintain the quality of the sessions as per ODL norms

$>$ Is it possible for university like IGNOU to impart training to such a massive number of counsellors across the country?

It is felt that the academic counsellor, besides acquiring skills and competencies, have to show inclination, self-interest and commitment towards the ODL system. They have to comprehend the fact that ODL system is learner-oriented and the emphasis is on learning and not teaching. The term Learning is defined as thinking, doing and practice. Apart from this, understanding the difference between tutoring and counseling must be uppermost in their mind and the focus should be towards counseling the learners including personal communication.

If these are to be fulfilled, then the counsellors are to be well informed about the ODL system, its sub-systems, and role of different stakeholders in the system, institutional profile, learners profile and their responsibilities during counseling sessions. This is possible only if there is a package of information system available or information system developed for whole gamut of activities taking place in ODL or IGNOU.

\section{INFORMATION SYSTEM FOR ACADEMIC COUNSELLORS}

Basically, the information is an important component in all spheres of life. The allpervasive information is most applicable to ODL institutions as the communication between the learners and the institution is the central point of focus in the learner support. In such a context, the success of the ODL system in IGNOU relies on how well the information sought by the learners is disseminated.

If the distance learner is not able to get updated information or delay in getting right information, the purpose of ODL methodology is defeated. In such a situation, the learner suffers due to lack of information and gets de-motivated in the self-study.

This leads to a tendency of not able to keep progress in the study and the probability of getting the studies postponed or thinking of dropping-out looms large in the minds of distance learners. 
To avoid and keep the distance learners motivation and their confidence high in the selfstudy, the academic counsellors, who meet the distance learners during the face-to face academic counseling sessions, must possess comprehensive information about the ODL or IGNOU system and procedures so as to set a right path to meet the expectations of the learners.

Therefore, a paradigm shift is required in the functions performed by the academic counsellors to maintain quality in a system like IGNOU where both quantity and quality have to be balanced. Therefore, it becomes imperative to develop a comprehensive information system for academic counsellors in ODL system with special reference to IGNOU for their capacity building. The management of information is utmost important for the counsellors to succeed in their role and responsibilities in dealing with distance learners, who till they complete their study always are in need of one or other type of information. It is a well known fact the whole gamut of information to be covered is wide in any ODL system in view of the fact that the operational network in any ODL system is not confined to a few activities and departments. It is an inter-link of various systems and sub-systems. In light of these facts, this study makes an analysis of information needs from the distance learners' perspective and builds an Information System, classifying the information into domains and sub-domains for the easy identification and classification of information for the academic counsellors.

The aim of developing such an information system for the academic counsellors is to build a repository of ready reference information which becomes handy for them in responding to any systemic ODL query posed by the learners in counselling sessions:

Information System for academic Counsellors in ODL

\begin{tabular}{|c|c|}
\hline Information domain & Information sub-domain \\
\hline 1.Institutional Profile & $\begin{array}{l}\text { - Organizational Structure of IGNOU } \\
\text { - Role and policy decisions of IGNOU hqrs } \\
\text { - Role of the Regional Centre } \\
\text { - Role of the Study Centre } \\
\text { - Responsibilities of Study Centre Coordinator and functionaries } \\
\text { - Programmes offered and their levels } \\
\text { - An overview of eligibility criteria and fee structure } \\
\text { - Study centres located in the region } \\
\text { - Programme activation at the study centre } \\
\text { - Working hours of study centre } \\
\text { - Duration of sessions prescribed course wise } \\
\text { - Dispatch and receipt of course materials }\end{array}$ \\
\hline $\begin{array}{l}\text { 2. Demographic Profile of } \\
\text { distance learners }\end{array}$ & $\begin{array}{l}\text { - Urban or rural background } \\
\text { - Social background } \\
\text { - Educational background } \\
\text { - Economic background } \\
\text { - Employment status } \\
\text { - Gap in years after previous study } \\
\text { - Previous Exposure to ODL system } \\
\text { - Access to study centre from place of stay } \\
\text { - Purpose of entering the ODL study }\end{array}$ \\
\hline
\end{tabular}




\begin{tabular}{|c|c|}
\hline $\begin{array}{l}\text { 3.Infrastructure at Study } \\
\text { Centre including } \\
\text { Information and } \\
\text { Communication facilities }\end{array}$ & $\begin{array}{l}\text { - Classrooms } \\
\text { - Library for reference of learners } \\
\text { - Radio broadcast- Gyan Vani FM radio station of IGNOU } \\
\text { - Television facility-24 hour Gyan Darshan satellite } \\
\text { channel uplinked from IGNOU hqrs. } \\
\text { - Teleconferencing facility } \\
\text { - Two-way video conferencing facility } \\
\text { - Use of website in IGNOU to gather learner-related information } \\
\text { - E-Gyan kosh platform containing repository of study } \\
\text { material in IGNOU website } \\
\text { - Website Information on Programme details, Admission, } \\
\text { re-registration, assignment and examination schedule }\end{array}$ \\
\hline $\begin{array}{l}\text { 4. Knowledge about Self- } \\
\text { learning material of } \\
\text { IGNOU }\end{array}$ & $\begin{array}{l}\text { - How self-learning material different from text books } \\
\text { - Structure of self-learning material (SLM) } \\
\text { - Division of SLM into Blocks and Units } \\
\text { - Instructional design of SLM } \\
\text { - Instructional events in SLM } \\
\text { - Access devices for easy identification } \\
\text { - Learning tools } \\
\text { - Content Structuring } \\
\text { - Content Presentation } \\
\text { - Content ordering } \\
\text { - Self-assessment questions to assess the progress of study } \\
\text { - Self-explanatory } \\
\text { - Self-directing } \\
\text { - Self-motivating } \\
\text { - Achieving learning outcome } \\
\text { - Facilitating retention, review, recall } \\
\text { - Time frame or hours to allot for self-study } \\
\text { Number of blocks and linkage with credit pattern }\end{array}$ \\
\hline $\begin{array}{l}\text { 5. Knowledge about } \\
\text { Programme Structure }\end{array}$ & $\begin{array}{l}\text { - Programme Structure } \\
\text { - Duration of the programme } \\
\text { - Minimum and maximum duration for the programme } \\
\text { - Course details } \\
\text { - Number of credits for the courses in a programme } \\
\text { - Number of theory Courses } \\
\text { - Number of Practical Courses } \\
\text { - Project Courses, if any } \\
\text { - Number of Credits to be completed in six months/one year } \\
\text { - Number of assignment responses to be completed as part } \\
\text { of continuous assessment }\end{array}$ \\
\hline $\begin{array}{l}\text { 6. Logistics in organization } \\
\text { of sessions }\end{array}$ & $\begin{array}{l}\text { - Preparing Counselling Schedule } \\
\text { - Intimating to learners } \\
\text { - Preparedness for the session } \\
\text { - Coordination with Study centre for holding sessions } \\
\text { - Maintaining attendance of learners at the sessions } \\
\text { - Duration and holding the sessions } \\
\text { - At the end of session reminding about the subsequent session }\end{array}$ \\
\hline
\end{tabular}




\begin{tabular}{|c|c|}
\hline $\begin{array}{l}\text { 7. Management in } \\
\text { handling of academic } \\
\text { counselling session }\end{array}$ & $\begin{array}{l}\text { - Informing and advising } \\
\text { - Tutoring and mentoring } \\
\text { - Counselling } \\
\text { - Guiding } \\
\text { - Promoting Learning: Thinking, doing and practice } \\
\text { - Motivating learners for self-study } \\
\text { - Clarifying doubts } \\
\text { - Interactivity among counsellor and peers } \\
\text { - Facilitating group work or discussion } \\
\text { - Learn to learn the study skills - Survey, } \\
\text { - Read, Review and Recall techniques } \\
\text { - Showing genuine interest towards learners } \\
\text { - Ability to listen } \\
\text { - Ability to observe and respond } \\
\text { - Skill to create dialogue with learners } \\
\text { - Hours of study to be put forth in a week } \\
\text { - Tips for writing assignments } \\
\text { - Tips for writing term-end examination } \\
\text { - Personal communication } \\
\text { - Use of Information and Communication Technologies } \\
\text { to better retention, review and recall of subject }\end{array}$ \\
\hline $\begin{array}{l}\text { 8. Role in Practical } \\
\text { sessions }\end{array}$ & $\begin{array}{l}\text { - Organising } \\
\text { - Informing methodology } \\
\text { - Guiding practical skills } \\
\text { - Hands-on experience of learners } \\
\text { - Improving analytical skills } \\
\text { - Improving problem solving skills } \\
\text { - Linking practical work with real-life experience } \\
\text { - Arriving at results and inference of results } \\
\text { - Report writing and Record maintenance } \\
\text { - Awarding marks for practical sessions }\end{array}$ \\
\hline $\begin{array}{l}\text { 9. What to look for in } \\
\text { assignments responses }\end{array}$ & $\begin{array}{l}\text { - Originality } \\
\text { - Content } \\
\text { - Presentation style } \\
\text { - Organisation of response } \\
\text { - Clarity } \\
\text { - Accuracy of Coverage } \\
\text { - Logical sequencing } \\
\text { - Summarizing }\end{array}$ \\
\hline $\begin{array}{l}10 . \quad \text { Tutor Comments } \\
\text { and Feedback through } \\
\text { Evaluation of Assignments }\end{array}$ & $\begin{array}{l}\text { - Continuous Assessment methods in ODL } \\
\text { - Knowledge about marking and grading system } \\
\text { - Preparing ideal assignment responses } \\
\text { - Evaluation of assignment responses of learners } \\
\text { - Knowledge of Tutor comments } \\
\text { - Skills for writing Margin Comments in every page } \\
\text { - Skills for writing Global comments summarizing } \\
\text { - overall performance } \\
\text { - Positive comments } \\
\text { - Constructive comments } \\
\text { - Justifying the grades or marks awarded } \\
\text { - Suggestion for future improvement } \\
\text { - Tutor comments act as two-way communication } \\
\text { and feedback to learners }\end{array}$ \\
\hline
\end{tabular}




\begin{tabular}{|c|c|}
\hline $\begin{array}{l}\text { 11. Administrative } \\
\text { Information }\end{array}$ & $\begin{array}{l}\text { - Schedule of submission of admission or registration form } \\
\text { - Programme fee details } \\
\text { - Examination schedule } \\
\text { - Date schedule for examination forms } \\
\text { - Submission of assignment responses } \\
\text { - Knowledge about change of address, course, medium etc } \\
\text { - Types of learners grievance and addressing authorities } \\
\text { - Break in studies and ways to continue } \\
\text { - Re-admission procedures after the maximum duration is } \\
\text { exhausted by learners }\end{array}$ \\
\hline $\begin{array}{l}\text { 12. Post study } \\
\text { information }\end{array}$ & $\begin{array}{l}\text { - Completion of programme } \\
\text { - Receiving grade card and provisional certificate } \\
\text { - Time of convocation } \\
\text { - Recognition of degrees and diplomas by other universities in } \\
\text { India and abroad } \\
\text { - Opportunities for higher studies } \\
\text { - Opportunities for seeking jobs } \\
\text { - Placement information } \\
\text { - Jobs in government, NGOs and industries }\end{array}$ \\
\hline
\end{tabular}

\section{CONCLUSION}

This study is able to develop comprehensive twelve Information domains along with subdomain information for the benefit and capacity building of academic counsellors in ODL system especially in the context of IGNOU. In any sphere of life, information to be communicated is very important for the activity to succeed. This is also applicable to ODL system especially for the academic counsellors who are the instrument for creating change in the minds of distance learners. It is a good understanding that the skills and attributes are very important for the academic counsellors and at the same time they have to be enlightened with the ideal information system on ODL for their effective discharge of duties at the counselling sessions. Keeping this objective in mind, comprehensive information is developed vis-à-vis the role of counsellors which is informing, advice and counselling. Certainly, the information system developed will help in the following ways:

$>$ Creating quality culture in the delivery of programmes

$>$ Effective conduct and disseminating information to learners

$>$ Helping the learner out of isolation and devote time to study

$>$ Intervention which keep the learners apprised about the updated information and facilitating the learners by way of avoiding time and energy in contacting different officials, IGNOU hqrs or Regional centre.

$>$ Infusing confidence in the minds of distance learners to undergo self-study without any hurdle.

$>$ Contributing for enhancing success rate among ODL learners

$>$ Playing a major role in retention of distance learners to complete the study

$>$ Acting as the ambassadors of ODL system in the society as the counsellors possess required information and thereby strengthening the ODL system in the country 
$>$ Creating a positive attitude among distance learners who get the expected satisfaction from the institution.

$>$ Finally, information system developed enhances the capacity building of the massive number of academic counsellors in ODL system, especially in IGNOU, to build the link between the distance learners and the ODL institution.

BIODATA and CONTACT ADDRESSES of the AUTHOR

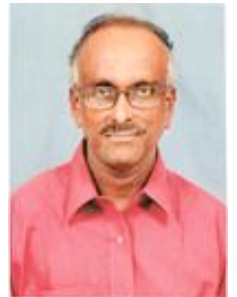

Dr. S. KISHORE is working in IGNOU for about two decades. At present, he is currently working as the Deputy Director, IGNOU Regional Centre, Madurai. He has published widely in the area of Distance Education. The main research interest in distance education are reaching disadvantaged groups, quality parameters in student support services in IGNOU, skill development through distance education, inclusive education especially training school teachers in the area of disability and cost analysis studies in distance education.

Dr. S. KISHORE, Deputy Director, Indira Gandhi National Open University

Regional Centre, Sikkandar Chavadi, Alanganallur Road, Madurai-625018. Tamilnadu, INDIA

Email: skishoredr1@gmail.com

\section{REFERENCE}

Das, M and Ghosh,C.K (2011). Academic Counselling in Distance Education: The Need and Expectations of IGNOU Learners, Indian Journal of Open Learning, 20(3):191-216. Indira Gandhi National University Profile (2013).New Delhi: IGNOU

Koul, B. N and Anita B. (1989). Handbook on Academic Counselling, New Delhi: IGNOU.

Mishra, S. (2005). Role and Competencies of Academic Counsellor, The Journal of Open, Distance and e-learning, 20(2):147-159.

Murugan, K. (1996). Selection as an Input for Counsellor Training: Some reflections, Indian Open Learning, 5(2): 59-69.

Srivastava, M and Reddy, V. V (2002). Academic Counselling at the Indira Gandhi National Open University (IGNOU): Counsellors' Perception, Malaysian Journal of Distance Education, 4(1): 15-30.

Tutoring in Open and Distance Learning: A Handbook for Tutors (2003). Vancover: Commonwealth of Learning. 